\title{
ISLAMIC EDUCATION IN INDONESIA AND MALAYSIA: The Existence and Implementation until $20^{\text {th }}$ century
}

\section{PENDIDIKAN ISLAM DI INDONESIA DAN MALAYSIA: Keberadaan dan Implementasi sampai abad ke-20}

\author{
Syaiful Akhyar Lubis \\ Faculty of Tarbiyah and Teacher Traning, \\ Postgraduate Program of State Islamic University of North Sumatra Medan \\ Email : saifulakhyar_lbs@yahoo.com
}

Naskah diterima 15 Februari 2017, direvisi 20 Meret 2017, disetujui 5 April 2017

\begin{abstract}
This study discusses the comparison between the existence and the implementation of Islamic Education in Indonesia and Malaysia both from religious educational institutions and public educational institutions. The main problem focuses on: what are the issues that covered equality and differences based on the existence and implementation, and also what matters are dominantly and substantially considered as supporting factors for the cause of those two points (existence and implementation). Methodologically, this study uses library research with qualitative approach as sources in writing. The study describes the policy from the two countries toward Islamic Education including their goals and objectives. In addition, this study is also exploring the development of Islamic Education in the two countries based on the historical facts and current situation. The result of this study indicates that Islamic education plays an important role in developing the both nations, and as such it is granted a special position in the national educational laws of both of these states.
\end{abstract}

Keywords: Islamic Education, Existence, Implementation

\begin{abstract}
Abstrak
Studi ini membahas perbandingan antara keberadaan dan implementasi Pendidikan Islam di Indonesia dan Malaysia baik dari lembaga pendidikan agama maupun lembaga pendidikan umum. Masalah utamanya berfokus pada: isu apa saja yang mencakup persamaan dan perbedaan berdasarkan keberadaan dan implementasi, dan juga hal-hal yang secara dominan dan secara substansial dianggap sebagai faktor penunjang penyebab dua poin tersebut (keberadaan dan implementasi). Secara metodologis, studi ini menggunakan penelitian kepustakaan dengan pendekatan kualitatif sebagai sumber dalam penulisan. Penelitian ini menggambarkan kebijakan dari kedua negara terhadap Pendidikan Islam termasuk tujuan dan sasaran mereka. Selain itu, penelitian ini juga mengeksplorasi perkembangan Pendidikan Islam di kedua negara berdasarkan fakta sejarah dan situasi saat ini. Hasil penelitian ini menunjukkan bahwa pendidikan Islam memegang peran penting dalam mengembangkan kedua negara, dan karena itu diberikan posisi khusus dalam undangundang pendidikan nasional di kedua negara ini.
\end{abstract}

Kata kunci: Pendidikan Islam, Keberadaan, Implementasi 


\section{INTRODUCTION}

Education meets the aims of comparative study only if it is related to the society and its country. Education is not only seen as an effort to develop the potential of the students, but it is also seen from its relationship with an individual, the society and its country. Every person has a different concept of what goals in education they want to achieve, which is not necessarily agreed upon by the rest of society at large. Therefore, each educational theory has its own characteristics which differ from others. It doesn't mean, however, that a society or a country should refuse other's concepts of education or ignore similar components in other's theories of education.

Similarly, the Islamic education of a certain country is the reflection of its philosophy and social medium which brings with it the Islamic philosophy of the country. of course, there might be similarities in the existence and implementation of Islamic education in some countries. However, since there are differences in culture, politics, society, economics, and the background of educational institutions, as well as schools of thought that Moslems might adhere to, educational institutions will certainly be distinguished from one another.

Indonesia and Malaysia are two countries which come from one family and both are members of ASEAN. Indonesia, with Pancasila as its principle and Moslems as the majority of its people, and Malaysia, which has made Islam the official religion of the country, undertake Islamic education in their educational institutions and also maintain it in their constitutions. The similarities and the differences between these two countries in carrying out Islamic education are discussed in the following chapters.

This study is quite imprortant to know how the Islamic education taught in Indonesia where Pancasila as state principle which officially acknowledges six faiths namely: Islam, Protestant, Catholic, Buddism, Hinduism and Confusianism. While Malaysia as a kingdom federal state only acknowledges Islam as state official religion. Therefore, this study is quite significant to know the existence and implementation the Islamic education in both countries up to $20^{\text {th }}$ century. Methodologically, the data sources of this writing are analysized from library research with qualitative approach.

\section{Literature Review}

As far as the writer has explored the literatures related to this tittle, the writer has not found yet the exact similar study with this tittle. So, this tittle is considered as a new finding. Because The study describes the policy from the two countries toward Islamic Education including their goals and objectives. In addition, this study is also exploring the development of Islamic Education in the two countries based on the historical facts and current situation. Eventually, the analysis of comparison emphasized on the existing facts and reality.

\section{Islamic Education In Indonesia}

\section{The Existence}

The study about the existence of Islamic education in Indonesia will be related to the history of Islam in Indonesia. Moslems as a majority in Indonesia, begin their history 
with the coming of Islam to Indonesia in the eight century or in the second year of Hijrah in Barus, west of Sumatera (according to the seminar on the coming of Islam to Indonesia, held in Medan in 1963). A long process was needed until the Islamic kingdom, Samudera Pasai in Aceh, in the $10^{\text {th }}$ century was finally established. ${ }^{1}$

As such, Islamic education through dakwah (preaching) developed without having its own certain place for a long period of time. After some time, it became situated in a place such as a house, sanctuary, or mosque (it was done in juz 'amma/al-Qur'an studying or book studying like tauhid, figh, tafsir, hadits). This took place for a long period of time until the pesantrens were finally built. Although it is not certain when and where the first pesantren was built, according to history, it can be known that in the $15^{\text {th }}$ century, a pesantren had been already built by Raden Fatah in east Java, also by Rangkang in Aceh in the Sultan Iskandar Muda government (1607-1636) and Surau in Minangkabau on the mid- $17^{\text {th }}$ century, and Pondok in west Java. ${ }^{2}$

During the era of Dutch colonial rule, Islamic education (referred to as a religious subject) was not included in the curriculum. Islamic education was just given as an extra subject in private schools like HIS met de qur'an, or Mulo met de qur'an. This was based on the policy of the government in chapter 172 (2) I.S (Indische Staatsregeling) stating

${ }^{1}$ Jurnalis Udin. 2007. "Profile of Muslim Education in Indonesia", Muslim Education Quarterly, vol. 5, no. 1, Cambridge: The Islamic Academy, p. 36.

${ }^{2}$ for the complete, see: Zuhairini, et al. 2008. Sejarah Pendidikan Islam, Jakarta: Dirjend Pembinaan Kelembagaan Agama Islam Departemen Agama RI, p.35. that: public teaching is neutral, meaning that it is given in respect of the individuals beliefs, and religious teaching could only be given out of school time. During Japanese colonialism, the government began to give extra attention to religious subjects (although it was just as a chastisement). It was presented in the form of visits to pesantren, including the moral subject (identic with Islamic teaching) in the state schools, and giving the allowance to build an Islamic High School in Jakarta lead by K.H Wahid Hasyim, Kahar Muzakar and Bung Hatta. $^{3}$

After the proclamation of independence of the Indonesian Republic, through the Ministry of Education, teaching and culture, the government started implementing the renovation of education in the schools, including religious teaching, madrasah and pesantren. Based on the government statement No: 1/SD/1946 on 3 January 1946 about the establishment of a Ministry of Religion Affairs, followed by the decision of the Ministry of Religion Affairs No: 1185/KJ on 20 November 1946 regarding religious education, Islamic education for general schools was officially managed by the government in December 1946. The management of religious education was formally and institutionally held by the Ministry of Religion Affairs and the Ministry of Education, Teaching and Culture. The two ministries are stated by the constitution in No: 1142/Bag. A (Teaching) and No: $1285 /$ K-7 (Religion) on the $2^{\text {nd }}$ of December 1946 , to manage the religious education in

${ }^{3}$ for the complete, see : Mulyanto Sumardi. 1999. Sejarah Singkat Pendidikan Islam di Indonesia 1945-1975, Jakarta: Dharma Bakti, p.11, and Zuhairini, et al., Sejarah, 2008, p.150. 
general schools (state and private schools); its organization in religious schools being managed by the Ministry of Religion Affairs. ${ }^{4}$

Followed by some decisions from the Department of religion, the Department of education and culture, and also joint decisions from both of these departments, this helped to clearly portray the existence of Islamic education Indonesian society. Moreover, if we see the reality of Islamic education, where the teaching process is a process that cannot be separated from its religious activities in any aspect, Islamic education and general education relate to one another. Therefore, The Committee of The Renewal of Nationality stated that religion shall be part of the National educational system. The relationship between Islamic education and general education is seen more clearly in the next formulation of the committee. ${ }^{5}$ Its existence was more firmly stated in the constitution of the Republic of Indonesia No: 2 on 1989 regarding the National educational system in chapter IV, in the $11^{\text {th }}$ article in the $1^{\text {st }}$ and $6^{\text {th }}$ verses, and a part of its explanation. ${ }^{6}$

The article states that the existence of Islamic education in Indonesia is strengthened by the constitution. Islamic education is an integral part of the National educational system, to the extent that Islamic education as a subject was integrated in the school curriculum from the lowest

${ }^{4}$ Departemen Pendidikan dan Kebudayaan RI. 2000. Laporan Komisi Pembaharuan Pendidikan Nasional, Jakarta: Depdikbud RI, p.18-35.

${ }^{5}$ Ibid, p.18-35.

${ }^{6}$ Sekretariat Negara RI. 2003. Peraturan Pelaksanaan Sistim Pendidikan Nasional, Jakarta: Armas Duta Jaya, p.196-197 and 223. level up to the highest level, be it in private or state schools.

\section{The Implementation}

Throughout the process of Moslem society in Indonesia becoming an Islamic kingdom having political power, the Moslems at the time awarded that education is a tool to reach the purpose of life and a tool to pass on good values (religion, culture, etc.) from one generation to the next. According to Hasan Langgulung, the main process of inheritance takes place through education. During that period, Islamic education was imparted informally through speaking (retelling method) which was related to the spreading of Islam to society. ' The teaching itself took place in a house, sanctuary, or mosque. Later on, the method changed to the hoffdelyk method (direct and individual) with defined lessons (reading juz 'amma/alQur'an, learning books: Tauhid, Fiqh, Tafsir, Hadits). The $15^{\text {th }}$ century is considered as the beginning of the appearance of pesantren (in east Java), followed by Rangkang in Aceh, Surau in Minangkabau and Pondok in west Java. Pesantren is the oldest educational institution in Indonesia where a student (santri) learns religious matters from a teacher (kyai, syekh) by using the sorogan method (studying individually, the student comestotheteachertaking thebooksthat will be studied). The teacher reads, the student listens and writes his/her explanation. The subjects studied were normally related to belief/tauhid, figh, reading of al-Qur'an and

${ }^{7}$ Hasan Langgulung. 2007. Manusia dan Pendidikan, Suatu Analisa Psikologi dan Pendidikan, Jakarta: Pustaka al-Husna, p. 147 
Arabic books (yellow books) in tafsir, hadits, lughat, etc. ${ }^{8}$

The development of the pesantren was finally disturbed by the constitution of general schooling (stbl. 118 No.4) established by the Netherlands (in Deandles period). The aforementioned constitution did not permit the teaching of any kind of subject without obtaining prior permission from the governor general. The Netherlands' hypocritical stance was proven by the help given to Christian Zending in Minahasa and Maluku to operate freely while tight regulation was given to the pesantrens in terms of teacher ordinance regulation. This raised awareness in the Moslems as to the necessity of building a general school where religion could be taught, and thus brought forth the idea of building a madrasah (by using a classical system of general subjects plus religion). The first madrasah known to exist in Indonesia was the madrasah adabiah in Padang (1907), established by Syekh Amarullah Ahmad (in 1915), it was changed to HIS Adabiah and became the first HIS imparting religious subjects in Minangkabau). The success of this centre of education was followed by the transformation of Sumatera Tawalib in west Sumatera into a madrasah in 1921 lead by Syekh Abdul Karim Amarullah. Furthermore, some ulamas established madrasahs in different areas of Indonesia, such as: K.H Wahab Hasbullah and K.H Mas Mansur (1914 in Surabaya, Rangkayo Rahmah Al Yunusiah), (1915) in Padang Panjang and K.H Hasyim Asy'ari (1919) in Tebuireng Jombang.9 In

${ }^{8}$ Ibid.

${ }^{9}$ for the complete, see: Mulyanto Sumardi. 2011. Sejarah, p. 49, and Mahmud Yunus. 2007. Sejarah Pendidikan Islam di Indonesia. Jakarta: Mutiara, p. 63. addition to that, some madrasahs were also established by religious social organizations, such as: (1) Muhammadiyah, 1912, madrasah ibtida'iyah, Tsanawiyah, Muallimin/Muallimat, Muballighin/Muballighat, Diniyah, (2) AlIrsyad, 1913, Madrasah Awaliyah, Ibtida'iyah, Tajhijiyah, Muallimin, Takhassus, (3) Matlaul Anwar, 1920, Madrasah Awaliyah, Ibtida'iyah, Tsanawiyah, Aliyah, Diniyah, (4) Nahdatul 'Ulama, 1926, Madrasah Awaliyah, Ibtida'iyah, Tsanawiyah, Muallimin Wustha, Muallimin Ulya, (5) Perhimpunan Umat Islam (PUI), 1927, Madrasah Pertanian, (6) Persatuan Tarbiyah Islamiyah (Perti), 1928, Madrasah Tarbiyah, Madrasah Awaliyah, Tsanawiyah, Kulliyah Syar'iyyah, and (7) al-Jam'iyatul Washliyah, 1930, Madrasah Tajhijiyah, Ibtida'iyah, Tsanawiyah, Qismul Ali, Takhassus. ${ }^{10}$ Some public schools were established to teach religion, such as: (1) Serikat Islam Schools, (2) Muhammadiyah Schools, (3) Sumatera Thawalib in Padang Panjang, (4) Nahdatul Ulama Schools, (5) Persatuan Umat Islam Schools, (6) al-Jamiyatul Washliyah Schools, (7) Al Irsyad Schools, and (8) Normal Islamic Schools. ${ }^{11}$

DuringtheperiodofJapanesecolonialism, there were virtually no problems. Japan allowed the operation of these schools, but teachers were not given any salary by the government, and the government watched out for any political activities, until the ministry of religion was established (now religious affairs) by the government of the Republic of Indonesia by PP No. 1/ SD/1946 on $3^{\text {rd }}$ January 1946. It serves the function of handling the development and

\footnotetext{
${ }^{10}$ see : Deliar Noer. 2012. Gerakan Modern Islam di Indonesia 1900 -1942. Jakarta: LP3ES, p. 69-95.

${ }^{11}$ Ibid.
} 
the implementation of religion in religious institutions (private or state). Based on the regulation of Religious Affairs No. 7/1952 that the madrasah's educational system is equal to: (1) Primary (ibtida'iyah), studying for 6 years, (2) elementary (tsanawiyah), studying for 3 years, (3) High (aliyah), studying for 3 years. Moreover, an Islamic college was also established, which later on became the IAIN which runs until now, followed by the STAIN with Islamic knowledge as the basis of the teaching-learning process.

Those madrasahs (except for IAIN, UIN, and STAIN) were organized by nongovernmental bodies (individual, institution, social/religious organization) and also by government subsidiaries. After being evaluated in 1967, the office of Religious Affairs changed 347 private madrasahs into state madrasahs with specification: 123 state primary schools (MIN), 182 state elementary schools (MTsN) and 42 state high schools $(\text { MAN })^{12}$

In 1975 the government issued the Peningkatan Mutu Madrasah dan Pengaruhnya Terhadap Pendidikan Islam Indonesia (SKB 3 Menteri), comprising of the ministry of Religious Affairs, No 6 year 1975, Ministry of Education and Culture, 037/U/1975, Ministry of Home Affairs No. 36 year 1975, regarding the increasing quality of madrasahs, by $30 \%$ for religious subjects and $70 \%$ for general subjects. Ibtida'iyah is equal to the Primary school, Tsanawiyah is equal to Elementary schools, and Aliyah is equal to High School. A certificate from a madrasah is worth the same (in its civil effect) as a certificate from

${ }^{12}$ for the complete, see : Djawatan Pendidikan Agama. 1959. Almanak Djawatan Pendidikan Agama, Jakarta: Sinta, p. 42. a general school in the equal level, and the students from madrasahs can continue their studies in a general school or move to a general school in the same level where the religious subjects given are allocated to same subjects, such as (1) Aqidah/Akhlak, (2) Ibadah/Syari'ah (3) Al-Qur'an/Hadits (4) Tarikh Islam. ${ }^{13}$

The implementation of Islamic education in general schools for the first time was arranged legally by the instance of SKB of the ministry of religious affairs and ministry of education and culture in 1946. Then it was followed by the next SK and the regulation and constitution used. Clearly in the GBPP of the ministry of education and culture in 1984, religious subjects were considered as obligatory subject matter in every level of general schools' curriculum, furthermore this became the core program to be followed by the students. Finally the UURI in 1989 regarding the National education system firmly stated that general educational institutions are also a place for the teaching-learning process of religion.

\section{Islamic Education In Malaysia}

\section{The Existence}

Education in Malaysia is a federal responsibility with the centralization of its administration system and with four classes of management, namely: various divisions of the ministry of education and federal departments of education in states, education offices in districts and schools.

${ }^{13}$ for the complete see: Departemen Agama RI. 198501986. Pedoman Umum Kurikulum Madrasah Ibtidaiyah, Madrasah Tsanawiyah, Madrasah Aliyah dan Garis-garis Besar Program Pengajaran, Jakarta: Direktorat Jendral Pembinaan Agama Islam. 
The one responsible for conducting the ministry of education is helped by two viceministers. The executor is the Secretary General of education, while the directors in each state are responsible for their own state. At first, language and education in Malaysia always faced ethnic contradictions, which lead to the educational system being broken down based on ethnic groups, so a national education system did not exist at that point in time. In 1950, in efforts to avoid subversive movements veering towards the cause of communism, they integrated the separated educational systems into one national system. In the beginning of the proclamation of independence era in 1957, this system was strengthened and was also employed in the socialization of the young generations of various ethnic groups into a Malaysian identity. ${ }^{14}$

Based on the spiritual constitution part I, section 3, verse 1 and 5 and also on the policy of the government's political philosophy that focuses on Islamic doctrines, Islamic education is the responsibility of the country, in this case referring directly to the kings of Malaysia. The government has the authority to allocate a certain amount of money as a budget for the management and also establishment of Islamic institutions, to spread religion and Islamic education amongst society and in the schools. Islamic education was made obligatory in every educational institution. But at the time, its existence can only be seen in private schools which had around 15 Islamic students. ${ }^{15}$

${ }^{14}$ Fatimah binti Ali. 2007. "The Malaysian Educational System and Islamic Educational Ideals", Muslim Education Quarterly, Vol. 4, no. 2, Cambridge: The Islamic Academy, p. 74.

${ }^{15}$ Ibid.
In 1961, Islamic education can be seen in the state schools that have around 15 Islamic students, based on Rahman Talib's Report (Penyata Rahman Talib) in 1961, section 36, verse 1. However, until 1979 religion was regarded as an elective subject. This meant that it had to be taken by students, but it would not be one of the subjects tested in national examinations. This ran until there was a regulation in the cabinet report (Laporan Jawatan Kuasa Kabinet) in 1979 that regulated a national examination for Islamic education in line with the other subjects, with its performance being under the responsibility of the Ministry of Education of Malaysia. ${ }^{16}$

In the beginning, Islamic education was under the control of the local government because it remained under the authority of the Malay kings (Grafted in the constitution part I, section 3, verse 1 and 5). Furthermore, after the launching of official documents in 1961 based on Rahman Talib's statement, the central government began exerting its authority to manage subject matters and operate Islamic education at all schools in Malaysia. This authority was carried out by a director in the ministry department of Malaysia, and was exercised in senior high schools only, while junior high schools were under the government's supervision and religious schools (state and private) were under the permanent regional government. Until 1974 the regional government gave the authority to the central government to arrange subject matters, thus the educational

\footnotetext{
${ }^{16}$ for the complete, see: Robiah Sidin. 2007. "The Inculcation of Islamic Values in The Malaysian Education System - An Overview", Muslim Education Quarterly, vol 4, no. 3. Cambridge: The Islamic Academi, p. 75-89.
} 
ministry department had a strong legal authority to control and arrange the implementation of Islamic education in the primary school and junior high school level. Until now, the implementation of Islamic education in the institutions is under direct authority of high educational institutions, based on the autonomy right which they possessed from the academic side. ${ }^{17}$

It is clear that the existence of Islamic education in the Malaysian state is under government control and regulation. It is part of the national education system, as such it cannot be separated from it, and as a lesson it has the same right with others, both in the curriculum as well as daily operation or in the implementing of state examinations.

\section{The Implementation}

When talking about the implementation of Islamic education in Malaysia, we will find there is a correlation with the history of Islamic propagation in Malayan society at first. The socialization of the Islamic doctrine, especially its belief and its religious services, started spreading by word-ofmouth and was then followed by the study on the Koran which was done in special houses, prayer houses and mosques, which lead to the development of boarding schools (Sekolah Pondok). According to Fatimah binti Ali, Islamic education in Malaysia nowadays is a realization from the development of Islamic traditional education. ${ }^{18}$

\footnotetext{
${ }^{17}$ compare with: Shafruddin Hashim. 2012. in: Sharom Ahmat and Sharon Siddique, Muslim Society, Higher Education and Development in Southeast Asia. Singapore: Institute of Southeast Asia Studies.

${ }^{18}$ Fatimah binti Ali. 2007. in: Muslim Education Quarterly, Vol. 4, no. 2, p. 77.
}

In learning the Koran, they were given the basics of Islamic teachings, the ability to read the Koran, reading and writing in Arabic to study books like: tauhid, figh, and hadits, meanwhile in the boarding schools lessons were given based on the teachers' expertise, so that there was a variation in each boarding school. Imparting the material at the third form of education referred to the individual system, and the classical system of students was determined by their mastering of the lesson given.

Until now, this sort of educational institution is implemented in the private sector by either individuals or an organization.

Initially, boarding schools were respected in society, which was proven by considerable interest from many to send their children to such schools (Annual report of the state of Trengganu for the year 1916). This had a positive influence on the development of the country in: Perak, Kelantan, Kedah, Seberang Perai, Riau and all the way to North Johor, and even agricultural areas (the south of Thailand).

The development of modern education in the $19^{\text {th }}$ century and the beginning of the $20^{\text {th }}$ century, according to Bilgrami and Ashraf, entered Islamic countries as cultural and political domination was separated from the Islamic educational tradition and this resulted in a change to a western systems at all levels. ${ }^{19}$ This in turn influenced the mindset of Malaysians to the point of them being convinced that the boarding school system was not suitable to their needs anymore and not suitable with modern life

${ }^{19}$ H.H. Bilgrami and S.A. Ashraf. 2005. The Concept of an Islamic University, Cambridge: Hodder and Stoughton The Islamic Academy, p. 32. 
in general. Therefore, they tended to send their children to schools operating under a western system of education, including those controlled by Christian missionaries. During this crisis, experts in Islamic education, especially the younger generation of Moslems, looked for new alternatives, and this brought forth the educational institutions called madrasah, which included general knowledge in their curriculum in addition to religious lessons, i.e. English, Geography, History and Mathematics. This educational institution applied the classical system, something which had not been done by boarding schools during this period. The organizer of these was the private sector or institutions, which were nonetheless under the control of the federal government. ${ }^{20}$

Based on the government's policy on education in 1958, the middle level of the madrasah was equaled to middle school (then called "Sekolah Ugama"), and thus became eligible for the low certificate of Malaysian education, middle certificate of Malaysian education, and high certificate of Malaysian education. In the official document (Akta Pelajaran) of 1961 there were other modern institutions mentioned beside the Islamic educational institutions, namely: 1) People's religious schools, 2) State religious schools, 3) Religious schools run by a religious council, and 4) Religious schools run by the ministry of education.

Since then, Islamic education was formally stated as compulsory in every public school existing in Malaysia, either in primary school, junior high, senior high or at the university level.

${ }^{20}$ Fatimah binti Ali. 2007. in: Muslim Education Quarterly, Vol.4, no.2, p. 77.
Formal education in Malaysia possesses a structure of 6-3-2-2 in terms of school periods, where this structure describes the levels of primary school, low middle school, high middle school and university, ${ }^{21}$ making it clear that the standard period of studying for the primary level is considered to be 6 years. For low middle class being 3 years and for high middle being 2 years, leaving for the university level an average of 2 years. Thus the presence of Islamic teaching is equaled on the structure and long-term learning at each school based on the class.

The control and supervision of implementing Islamic education in public schools, religious schools and universities is arranged into a clear classification. General schools are under the authority of the central government through the ministry of education's department of Islamic education. Religious schools are placed under the authority of the regional government, while the implementation in institutions of higher learning remains under their own authority based on the academic autonomy right they possess. As a matter of fact, Malaysia did not have a special religious university, and the International Islamic University in Malaysia belonged to an Islamic organization, thus its control and supervision was not under the Malaysian government's authority in absolute terms. Clearly, this mechanism was designed and arranged taking into consideration both law and government regulations existing in the field of education.

\footnotetext{
${ }^{21}$ Kedutaan Besar Malaysia.2007.Jakarta, Malaysia Secara Ringkas, Jakarta: Bahagian Penerangan, p. 9.
} 


\section{Comparison Analysis, A Conclusion}

\section{Similarity Aspects}

As Moslem majority states, it is visible that the existence of Islamic education in Indonesia and Malaysia is interrelated with the presence of Islam in these countries as well as national life. Indonesia, with its philosophy consisting of five principles (Pancasila) guarantees freedom of religion to its citizens, and Malaysia, which made Islam as the state's official religion and also orientated the government's wisdom towards Islamic education, not only in religious educational institutions but also in general educational institutions at all levels, directly involves the government in its implementation.

For states that have been colonized such as Indonesia and Malaysia, education carries an important meaning in the struggle for independence. That is why in the laws of education of each state it is clear that the goal of national education is to build the national intellect through physically and mentally strong citizens whose efforts can bring forth prosperity and safety to the people and the state. In forming these complete citizens, both states agreed to make Islamic educational values as the operational substratum in their efforts to accomplish this.

History has shown that the implementation of Islamic education in both of these states is rooted in a similar history. It was begun by Islamic religious proselytizing practices and then developed into the Madrasah system, called Sekolah Ugama in Malaysia. Both of these states share a similarity in the implementation of Islamic education in general educational institutions, in that both of them suffered oppression from colonial domination, so that only after independence were they able to accomplish this task.

Nowadays, Indonesia and Malaysia have implemented Islamic education in general schools in addition to religious schools. Islamic education as a subject has been integrated in school curriculums for all educational levels from primary school to university.

From this point of view, it is clear that Islamic education in both states have produced well-known Muslim figures as founding fathers of the states who play their roles to develop the nations such as KH. Hasyim Asy'ari, Syekh Abdul Karim Amarullah, HOS. Cokroaminoto, Muhammad Nasir etc., and in Malaysia: Tengku Abdul Razak, Datuk Hussein Onn, Mahathir Muhammad etc.

\section{Different Aspects}

In controlling and supervising the system, the implementation of Islamic education in these countries does show differences. In Indonesia, the implementation of Islamic education in general schools is under the control of the national educational and religious departments. While in religious schools, it is under the religious department. Thus, this supervision system and its implementation steered towards centralization. In Malaysia, the implementation of Islamic education in general schools, namely primary and elementary schools, is controlled by part of the Islamic ministry of education or central government. For the university level, the implementation and supervision are the 
responsibility of the university itself. While in religious schools, the supervision is undertaken by the local government. This is the direct product of the Malay kings having the power to arrange religious affairs throughout the country, including those involving Islamic education. Therefore in Malaysia there are two implementation systems, for general schools based on centralization and for religious schools based on decentralization.

Another difference can be seen in that Indonesia has Islamic universities such as IAIN (State Institute of Islamic Studies) and STAIN and also private Islamic universities which are supervised by the Religious Ministery. Nevertheless, for uniformity of Higher Education in Indonesia IAIN and STAIN are also subject to and controlled by Ministery of Research and Technology and Higher Education. Then, at the beginning of $21^{\text {st }}$ century some IAIN have been developed into UIN (State Islamic University) where Islamic characteristic general faculties such as Medical, Science and Technological, Literature, Social and Political ones established. Unlike Malaysia, where religious university institutions are regarded as a faculty under public universities, without the existence of any private universities.

Moreover, there are differences regarding the length of study periods in the primary school and middle school level between Indonesia and Malaysia. In Indonesia, the educational period is shaped into a 6-3-3 structure, that is to say, 6 years for primary school, 3 years for junior high school and 3 years for senior high school. While in Malaysia the study periods reflect a 6-3-2-2 structure, meaning to say 6 years for primary school, 3 years for low middle school, 2 years for high middle school, and an additional 2 years for pre-university courses. Primary school is made compulsory up until the 9th grade.

A clear difference reflected between both states concerns the implementation of Islamic education as curriculum subject matter and as a lesson forming part of state examinations. In Indonesia, Islamic education is made as equally compulsory as the rest of the general subjects forming part of the curriculum. Such a regulation has been effective since December of 1946, though officially then stated at Law No 2/1989 regarding National Education System Chapter IX Article 39 point b. While in Malaysia, such an occurrence has not taken place.

\section{CLOSING}

The development of modern education bought forth changes in the implementation of Islamic education in Indonesia and Malaysia, be it in the system itself or in terms of its curriculum. This happened due to views considering that traditional Islamic educational institutions could not fulfill the demands of society and which argued that the existing system was not suitable with modern life anymore. From this issue, arose the idea to create an Islamic educational curriculum in the Madrasah (in Malaysia called Sekolah Ugama), which was then followed by the renovation of educational policies in both of these states up until now.

Islamic education plays an important role in developing the both nations, and as such it is granted a special position in the national educational laws of both of these states. Although perspectives still exist 
which place Islamic education as a second class subject which is regarded to be on a lower level when compared to general education subjects, these same problems bring forth the realization that Islamic education must play an important role in an individual's life, so that it can be felt in every aspect of society.

\section{BIBLIOGRAPHY}

Ahmat, Sharom and Siddique, Sharon. Muslim Society, Higher Education and Development in Southeast Asia. Singapore, (2012): Institute of Southeast Asia Studies

Bilgrami, H.H. and Ashraf, S.A. (2005): The Concept of an Islamic University. Cambridge, Hodder and Stoughton The Islamic Academy

Departemen Agama RI. (1985/1986): Pedoman Umum Kurikulum Madrasah Ibtidaiyah, Madrasah Tsanawiyah, Madrasah Aliyah dan Garis-garis Besar Program Pengajaran. Jakarta, Direktorat Jendral Pembinaan Agama Islam

Departemen Pendidikan dan Kebudayaan RI. (2000): Laporan Komisi Pembaharuan Pendidikan Nasional. Jakarta, Depdikbud RI

Djawatan Pendidikan Agama. (1959): Almanak Djawatan Pendidikan Agama. Jakarta, Sinta

Fatimah binti Ali. (2007): "The Malaysian Educational System and Islamic Educational Ideals", Muslim Education Quarterly, Vol. 4, no. 2.
Kedutaan Besar Malaysia Jakarta. (2007): Malaysia Secara Ringkas. Jakarta, Bahagian Penerangan

------------. Pendidikan di Malaysia. (2007): Jakarta, Bahagian Perencanaan dan Riset Pendidikan

Langgulung, Hasan. (2007): Manusia dan Pendidikan, Suatu Analisa Psikologi dan Pendidikan. Jakarta, Pustaka al-Husna

Noer, Deliar. (2007): Gerakan Modern Islam di Indonesia 1900 -1942. Jakarta, LP3ES

Sekretariat Negara RI. (2003): Peraturan Pelaksanaan Sistim Pendidikan Nasional, Jakarta, Armas Duta Jaya

Sidin, Robiah. (2007): "The Inculcation of Islamic Values in The Malaysian Education System - An Overview", Musim Education Quarterly, vol 4, no. 3.

Sumardi, Mulyanto. (2011): Sejarah Singkat Pendidikan Islam di Indonesia 1945-1975. Jakarta, Dharma Bakti

Udin, Jurnalis. (2007): "Profile of Muslim Education in Indonesia", Muslim Education Quarterly, vol. 5, no. 1.

Yunus, Mahmud. (2007): Sejarah Pendidikan Islam di Indonesia. Jakarta, Mutiara

Zuhairini, et al. (2008): Sejarah Pendidikan Islam. Jakarta, Dirjend Pembinaan Kelembagaan Agama Islam Departemen Agama RI. 